\title{
Organized Crime In The Balkans
}

\author{
Dr. iur. Kole Krasniqi \\ University of Peje, Kosovo
}

doi: 10.19044/esj.2016.v12n19p204 URL:http://dx.doi.org/10.19044/esj.2016.v12n19p204

\begin{abstract}
Legal systems are put in jeopardy and social stability and welfare are harmed wherever there are organized criminal activities. In the Balkans, organized crime is also tantamount to a main obstacle to the European integration of the region. The permanent influence of organized crime on the state structures, the cooperation between different criminal organizations and especially their collaboration with some extremist groups impact political stability in an extremely negative way. The states in the Balkans have recognized the dangers for their peoples constituted by organized crime and have already taken a number of required legal, institutional and political measures in order to be able to successfully combat organized crime. However, organized crime still constitutes the main risk to the new democratic states in the Balkans in spite of these measures. For that reason, combating organized crime may not treated just as the task or responsibility of one single state but it needs to be understood as an obligation and responsibility of all the states in the entire region as well as of the European Union. Therefore, cooperation and coordination of joint activities for combating organized crime have to be based on modern international standards. Besides, a continual perspective is required according to the interest of the peoples of the region to live together in peace and mutual harmony and to establish a society where human rights are not threatened by criminal violence but protected just like in the European Union.
\end{abstract}

Keywords: Organized Crime, Balkans, Corruption, economic Crisis

\section{Introduction}

The Balkans is a geopolitical region of Southeast Europe that includes an area of $550,000 \mathrm{~km}^{2}$, where about 55 million people with different identities, who sometimes are in adversarial ethnic, cultural and political positions, live together (Okey, 2007).

Such confrontations led to the discourse of the Balkan Peninsula where the word "Balkanism" was increasingly used during the nineteenth century to refer to a disintegrating geographic area in which small states and 
the states which had been recently liberated from the Ottoman Empire developed expansionist policies towards each other, committed cruel acts of violence against members of other peoples and instigated various ethnic conflicts in the Balkans. So over the last two centuries, the Balkans has been adequately treated as a problematic area of Europe by the Western World (Hobsbawm, 2005).

After the end of the ethnic conflicts of the twentieth century, the Balkan countries, supported by the European Union and the U.S., started opposing the past practices of confrontation among each other by engaging in active policies of mutual friendship and cooperation as fundamental European values. Since that time, the Balkan countries have begun more openly to reject their being labeled as "Balkan countries", on the grounds that their countries no longer undergo ethnic or political crises and that there they have passed their own bills of rights into laws and have built functional institutions according to European models (Hobsbawm, 1990).

In reality, despite many successes that have been achieved in some regions of the Balkans, there are still obstacles re: the functioning of the rule of law and the development of a democratic life.

These countries, which have been characterized by a relatively low degree of economic development and by significant deficits in their democratic education, are faced with two new enemies, called "organized crime" and "corruption", after they have left the bloody mutual conflicts of the past behind and established democratic governments.

There can be no doubt that these criminal phenomena which are present in different forms and sometimes accompanied by various national or religious sorts of extremism are tantamount to a major disruptive force for any attempt to achieve social development and the cultivation of democratic values in this part of Europe (Krasniqi, 2009). Therefore, the successful fight against these criminal phenomena amounts currently to the main challenge for the new democratic governments in the Balkans and South Eastern Europe (Department of Crime Problems, 2005).

\section{The Emergence And Development Of Organized Crime In The Balkans}

Historically the Balkans served as a bridge between Europe and Asia. In this way, the Balkan Peninsula was also used by various criminal groups as a transit country for trafficking and smuggling various goods to Europe. Despite these activities having taken place for centuries, the phenomenon of organized crime in the Balkans has only become so alarming during the last decades of the twentieth century (Stojarova, 2011).

Specifically, the great economic crisis of the early 80-ies of the XX century that gripped the former Yugoslavia and other countries of Eastern Europe, followed by economic sanctions and various political conflicts, 
provided optimal conditions for the emergence of organized crime in the Balkans. Meanwhile, social factors as well as legal and institutional vacuums, which developed during the transition period most of the countries in the region underwent, contributed to the rapid development of organized crime in the Balkans so that after a short time, the whole Balkan region had become one of the most important epicenters of the international organized crime (Stojarova, 2012).

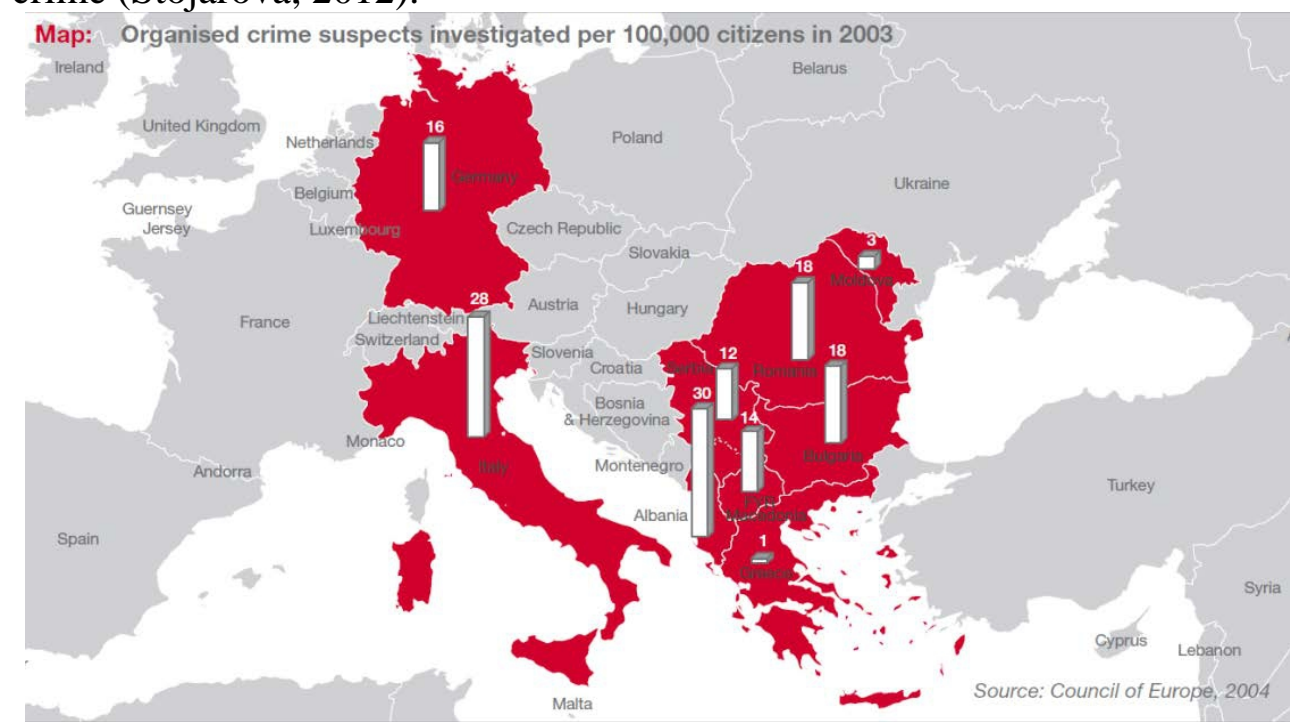

Number of suspected persons in the involvement of organized crime per 100,000 inhabitants in 2003 UNODC, Crime and Junior Impact on the Balkans, Vienna International Centre 2008. p.12

The main factors that have contributed to the emergence and development of organized crime in the Balkans are:

\section{The Geographical Position}

Short-cuts crossing through the Peninsula link Europe with the Middle East and Asia. This geographical position has caused the "Balkan Route" to be used for smuggling people and various goods from Asia and the Middle East to Europe and vice versa more than any other historical, cultural or national factor.

\section{The Balkan Route}

After heroin had been discovered on 21. 08. 1897 by the German scientist Felix Hoffmann, it was at the time considered "an effective drug against cough and pain" and called heroin because it was thought to be a heroic discovery back then. It soon started to be consumed on a large scale in some European countries (cf. Briesen, 2005). Several international conferences were organized in Shanghai (1909), Den Haag (1912, 1913, 1914) Geneva (1925, 1931, 1936) etc. ( Schmidtbauer/v. Scheidt, 1999), 
because of the alarming dimensions of drug addiction. Due to some different political and social influences, some European countries passed their first laws against the consumption and trafficking of narcotics. These restrictions obviously had a considerable impact on the beginning of secret and illegal drug trafficking towards Europe (UNODC, 2011).

One of the main routes for drug trafficking from Turkey and other Asian countries to Europe is the so-called "Balkan route". According to the international agencies for fighting organized crime (Interpol, Europol and the Global Monitoring Agency based in Paris Drug / Observatoire des Drogues Geopolitique), the "Balkan route" came more and more into use during the 1970's. Due to the geopolitical advantages on the Balkans, this route had become one of the most important venues for human trafficking and drugs smuggling towards Europe after 10 years (UNODC, 2011).

This is also evidenced by the data published by the International Organization for Migration (IOM), according to which about 400,000 women are being trafficked to Europe through various routes over the Balkan each year, while the number of trafficked women in the Balkan countries is estimated to be around 170,000 (Amnesty International,2004).

Other international organizations also state that the trafficking of prohibited goods through the "Balkan Route" is extremely alarming. According to the United Nations Office on Drugs and Crime (UNODC), about 65 tons of heroin reached the Balkans in 2009, of which 14 tons were trafficked to Italy and the rest, amounting to 45 tons, was trafficked towards the UK, Holland, France and Belgium (UNODC, 2011).

However, after two years, the extent of drug trafficking through the "Balkan Route" had increased significantly. According to Europol, about 100 tons of heroin came to the Balkan in 2011, of which 85 tons were smuggled into the direction of the European Union (Europol, 2011), mainly through:

- $\quad$ the "Classic Route," which begins in Turkey and goes through Bulgaria, Macedonia, Kosovo, Serbia, Bosnia and Croatia, towards the European Union;

- $\quad$ the "Northern Route", which also begins in Turkey and goes through the Black Sea and Ukraine or Bulgaria, Romania, Hungary, towards Austria and Slovakia; and

- $\quad$ the "Southern Route", passing through Greece, Macedonia and Albania to Italy (cf. Baghdoyan, 2003). 


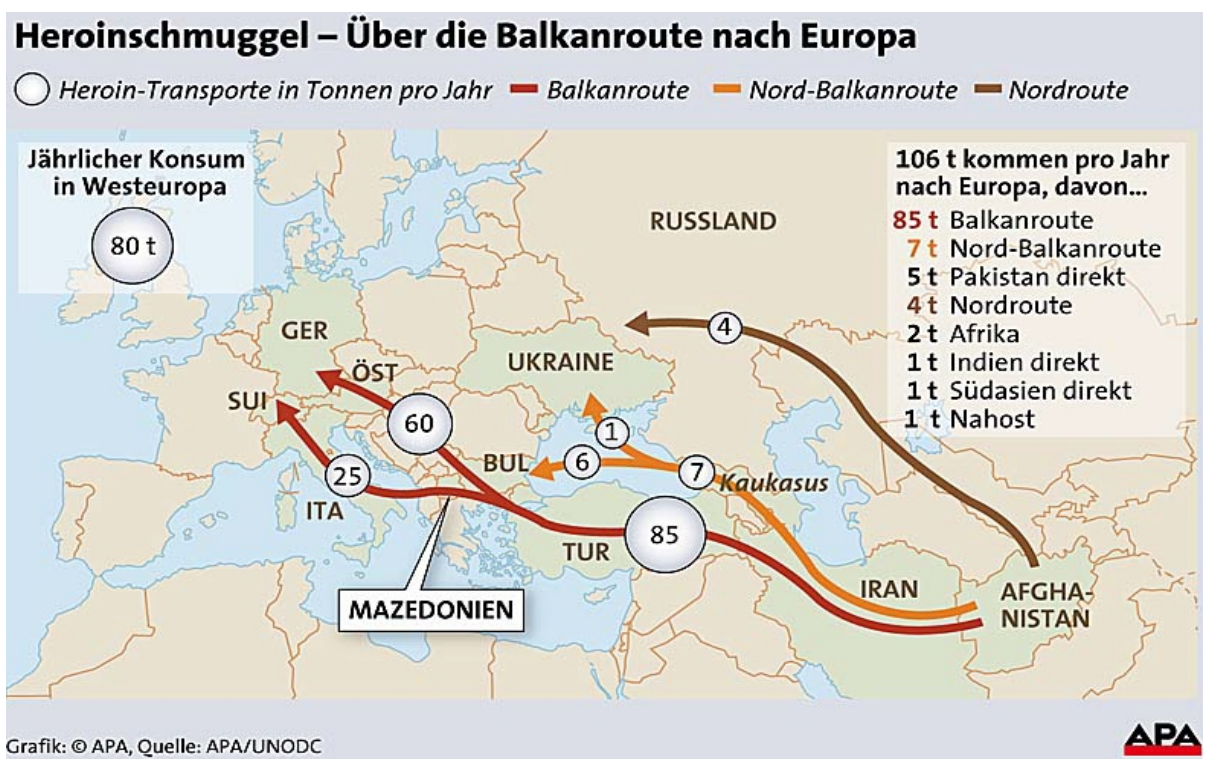

Confer: United Nations Office on Drugs and Crime, UNODC World Drug Report 2012. Heroin, p.122

According to some analysts, the criminal groups operating along the "Balkan Route" gain about 2 billion $€$ per year merely by selling the drugs that were produced in Afghanistan (Kosta, 2011).

This massive financial benefit has obviously led to an increasing number of crimes and raised the level of corruption in several Balkan countries. Regional criminal groups got so strengthened that they are operating on a global scale by now.

A typical example is the capture of 486 kilos of cocaine originating from Venezuela at a border-crossing point between Kosovo and Macedonia (City of Skopje, 2008).

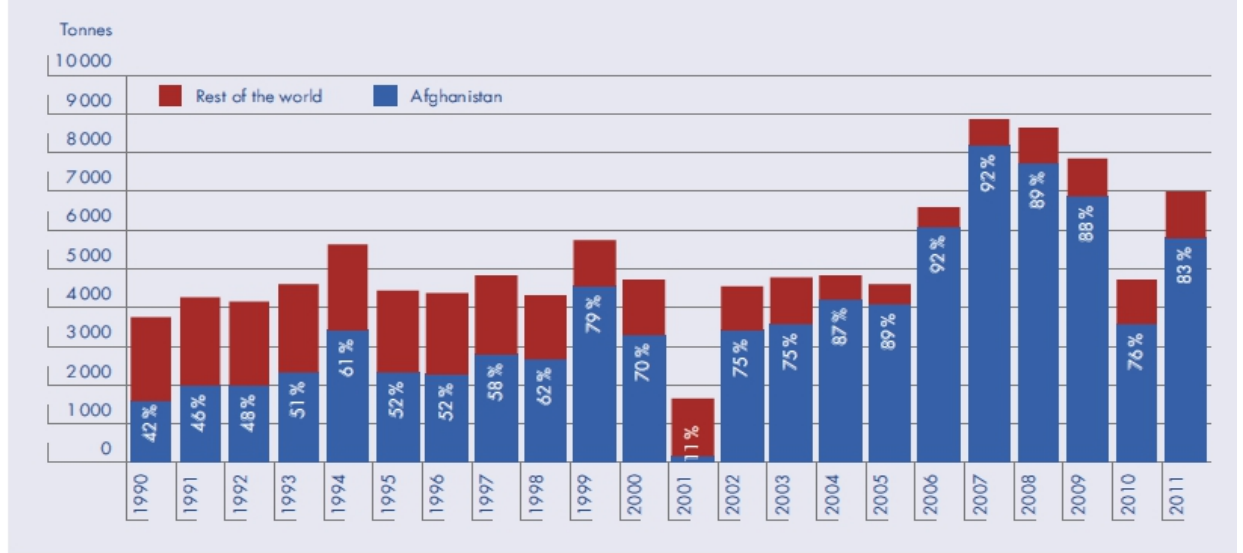

ISource: UNODC (2007, 2008a, 2012al.

Estimate about the illegal drugs production in Afghanistan 1990-2011 - According to the UNO, $3 / 4$ of all the heroin that is trafficked worldwide stem from Afghanistan 


\section{The Liberalism Of Yugoslavia}

During the late '70s of the XX century, the Yugoslav regulations for the movement of persons and goods were rather liberal. Meanwhile, in all other dictatorial countries of the region, such movements were much more limited and strictly controlled. Undoubtedly, this sort of economic liberalism (compared to other countries in the region) and geopolitical advantages offered by the Yugoslav state had a lot of influence on the Balkan Route being used for trafficking and smuggling various goods to Europe and vice versa.

\section{The Economic Crisis}

During the last decades of the 20th century, former Yugoslavia and other socialist countries were facing a major economic crisis, which had caused a drastic economic downfall and a radical increase of inflation and unemployment. The economic crisis resulted in severe political tensions mainly among different Yugoslav republics as well as in Moldova.

Under such circumstances characterized by seriously weakened institutions, organized groups of individuals involved in criminal activities, such as human trafficking, smuggling of drugs, counterfeits of diplomas and other official documents, financial fraud, etc. came into existence in the region.

\section{Corruption}

The economic crisis, political tensions and the weakened state institutions enabled the development of corruption all over Eastern Europe. Officials of these countries, disappointed by the communist ideology and demoralized by their low salary, were not showing any interest in public welfare, but were merely concentrating on their own rapid and illegal financial advancement. Thus, through corruption, illegal contacts and networks were created between government officials, mainly from customs services, the police, the tax administration and the health care and education system etc. on the one hand and criminal structures on the other hand, which has undoubtedly contributed to serious criminal activities and the development of organized crime in the Balkans.

\section{The Sanctions Of 1992 Against Former Yugoslavia}

The consequences of the restrictions on the import, export and transit of sanctioned goods within the territory of the former Yugoslavia during the 90s led to the appearance of criminal groups that cooperated with each other and particularly so with Milosevic's regime in order to access channels for the import or export of prohibited goods or to act as mediators in supplying the Serbian market with scanty goods, such as fuel, rare sorts of medicine, 
tobacco etc. Under these circumstances any form of smuggling was legalized and all those who broke the UN blockade were treated by the Serbian propaganda as "heroes" (Kosovo Democratic Institute, Prishtina 2011). Thus, all the towns and cities along the Serbian border became an area of trafficking and smuggling. The difference between state-organized crime, on the one hand, and corruption and mafia, on the other hand, became invisible under these circumstances. Serbian criminal groups from all the territories of former Yugoslavia, tolerated and supported by the state, had gained so much power as to exert a strong political influence. Due to the contacts established with the Albanian mafia groups, the UN embargo was broken, making it possible to supply the Bosnian Serbs and the Yugoslav army with fuel. Meanwhile, due to the support of the Macedonian mafia, approximately 1,000 trucks crossed the Macedonian border to Serbia each week (cf. Hislope, 2001).

\section{The Weapons Embargo}

The weapons embargo had prevented several opposed republics of Yugoslavia from buying arms legally. In the event of war, they were forced to buy weapons on some regional and international black markets. However, the payment of these weapons was usually made by uncontrolled budget positions and voluntary funds. During these transactions, major financial frauds were committed, some of which have ended up in the courts, such as the "Diamonds affair" involving the Croatian General Vladimir Zagorec (Zagorec, 2010) etc. Since then, several regional groups belonging to the organized crime have been involved in weapons trafficking.

After the fall of the Ponzi schemes in Albania and the resulting chaos, police depots and military arsenals were massively looted under the absence of the rule of law and in a context of wars between rival clans. The trafficking of these weapons on domestic and regional markets contributed to the creation of various local gangs and their rapid development into organized criminal groups.

\section{The Transition}

The dismantling of Yugoslavia and the collapse of the socialist regimes in Albania and in other countries of the former socialist bloc marked the beginning of the transition period. This time implied the start of significant structural changes and the transition of a state-controlled society to a democratic one. During this period of great economic, legal and political transformations, legal and institutional loopholes were created which enabled the development of various organized criminal activities in many countries in the Balkans. 
The extent of the development of organized crime has recently caused the Balkan region to be treated not only as a transit region but increasingly considered a place of destination and storage for drug trafficking, human trafficking, weapons smuggling and money laundering as well as a place where various forms of organized economic and financial crime are committed (US Department of State, 2013).

The alarming fact that the number of users of different sorts of drugs at the same time has increased in the Balkans during the recent years should also be mentioned (Carpo, 2006).

According to some analyses, the Balkan countries have been found to be places where drugs are cultivated (mainly cannabis sativa), where marijuana and hashish oil is produced, and where all kinds of drugs have been abused and traded during the recent years (cf. Qaja, 2011 ). Therefore, Europol explained that the dominant region for the production of the hashish that supplies the EU market is Albania, followed by Serbia, Bulgaria and Kosovo (Mapo, 2013).

According to this source, the cannabis cultivated in Albania, Macedonia and Kosovo region is not only distributed in Greece, Italy, Slovenia, and Hungary but also trafficked to Turkey with the aim of exchanging it over there with heroin.

\begin{tabular}{|l|c|}
\hline \multicolumn{1}{|c|}{ Country/Territory } & $\begin{array}{c}\text { Estimated number of heroin } \\
\text { users }\end{array}$ \\
\hline Albania & 8,535 \\
\hline Bosnia and Herzegovina & 8,099 \\
\hline Croatia & 10,749 \\
\hline $\begin{array}{l}\text { The former Yugoslav } \\
\text { Republic of Macedonia }\end{array}$ & 8,000 \\
\hline Montenegro & 635 \\
\hline Serbia & 17,875 \\
\hline Kosovo & 5,000 \\
\hline Total (for the region) & $\begin{array}{l}\text { Note: Figures in Table } \\
\text { not reflect the real sit }\end{array}$ \\
\hline
\end{tabular}

Another alarming fact is that not only drugs which are produced in Afghanistan, Iran, Turkey, Albania and Macedonia pass through the Balkans to Europe. Acetic anhydrite which is produced in the European Union and is used for the production of heroin in Afghanistan and Turkey is also smuggled on the Balkan Route to Turkey and other Oriental countries (Europol, 2011). Classical synthetic drugs such as Amphetamine, Ecstasy and new drugs which are mainly produced within the European Union where 41 new psychoactive substances were discovered in 2011 alone are also smuggled on the Balkan Route to Turkey and the East. The said drugs had 
been produced in about 90 illegal labs that had been operating in all the states of the European Union (cf. Europol, 2011).

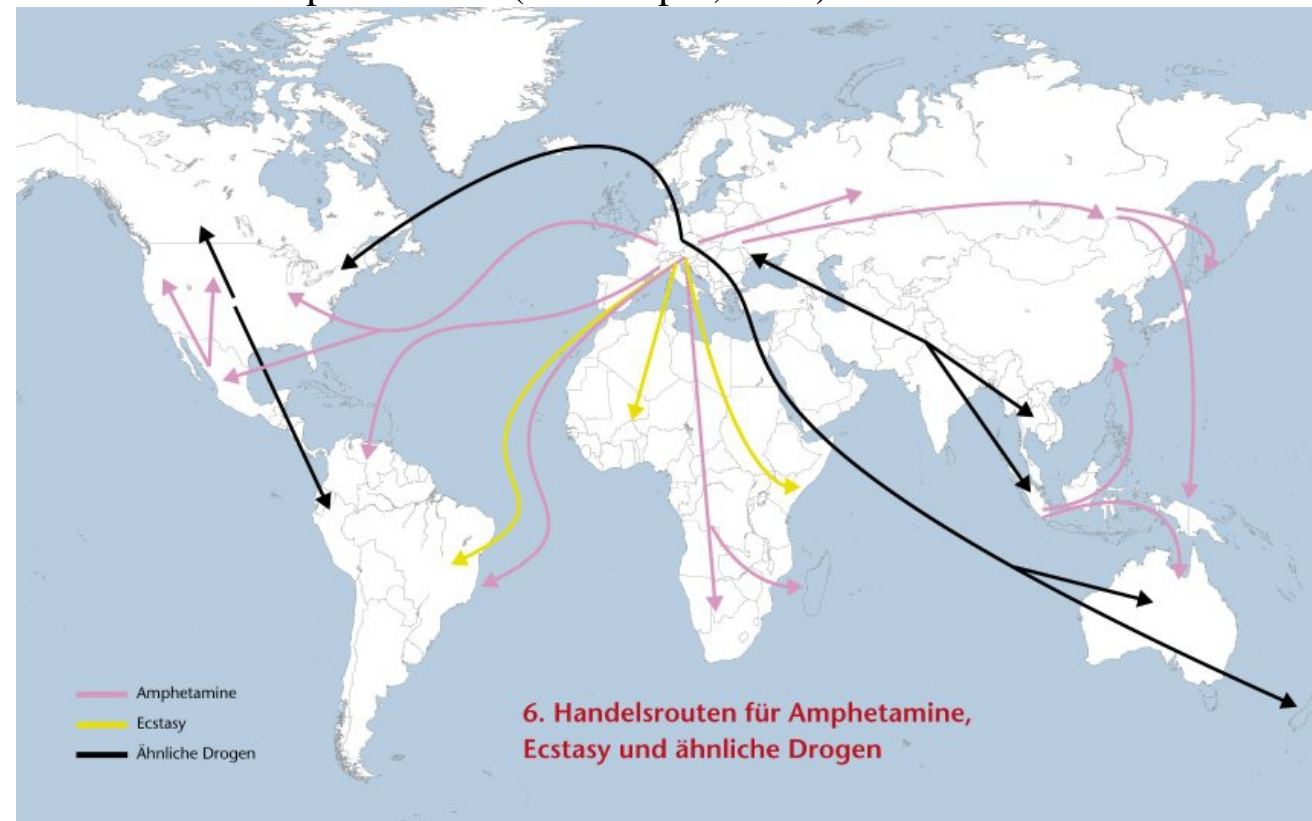

Amphetamine and Ecstasy trafficking (Spiegel Online, 2010 )

\section{Cooperation Between Criminal Groups In The Balkans}

Organized crime in the Balkans could not have developed to this point without establishing networking and cooperation between regional groups belonging to organized crime. These groups, becoming more and more criminally sophisticated all over the Balkans, are characterized by their ability to work together and to adapt to any new social circumstances well enough in order to achieve their criminal goals.

This is evidenced by the fact that the development of recent ethnic wars in former Yugoslavia or the armed conflicts in Moldova, Romania and Albania have not brought about the termination of such sorts of cooperation between criminal groups in the region - regardless of their belonging to "opposed" ethnicities or religions. In reality, these criminal groups have always cooperated with each other in the area of drug smuggling, human trafficking, smuggling of stolen vehicles, cigarettes smuggling, weapons smuggling, fuel smuggling and money laundering despite their strong but merely formal nationalistic rhetoric.

The "theft" of 930 passports from the Croatian Consulate in Mostar and their distribution throughout the territory of the former Yugoslavia ( Daskalović, 2003), the smuggling of Serbian weapons and goods into Kosovo (Region Press, 2013), the smuggling of "Made in Kosovo" cigarettes into Serbia and the Republika Srpska in Bosnia etc. clarify this point. 
Such kinds of cooperation between regional groups of organized crime is also evidenced by plenty of investigated cases when individuals from all over the Balkans, such as Albanians, Serbs, Bosnians, Montenegrins, Turks, Hungarians, Austrians, Ukrainians, etc. have been taken to court as suspected criminals (Riegler, 2003).

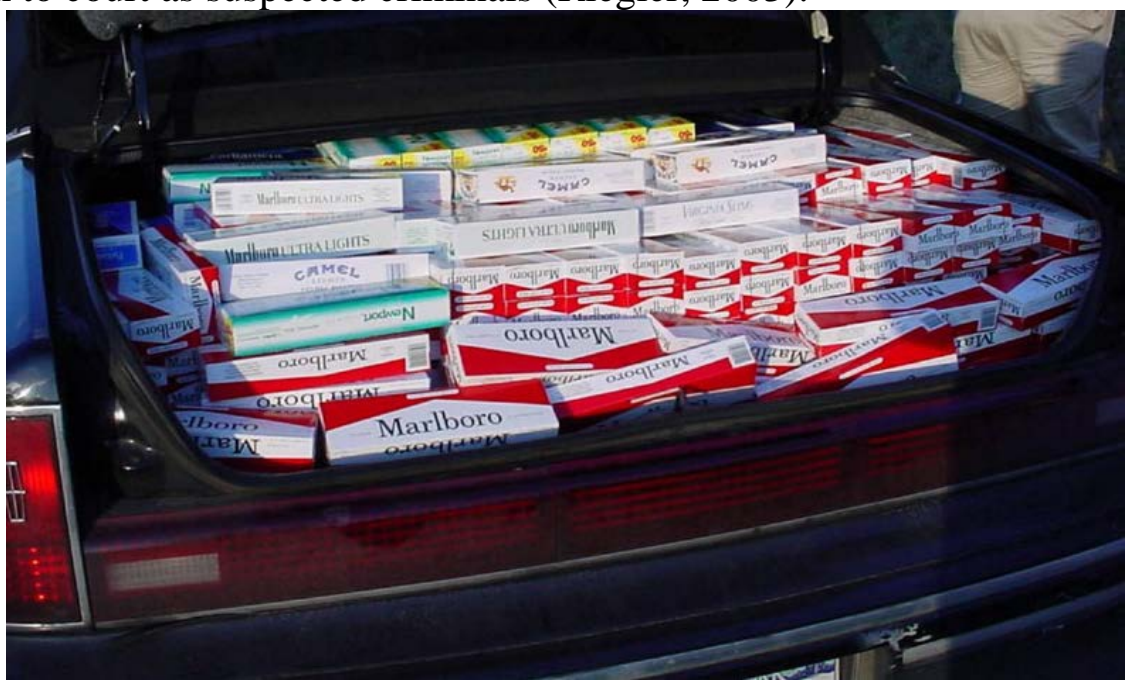

Cigarettes with "Republic of Kosovo" occupy kiosks in "Republika Srpska" and Serbia (Presheva Online, 2013).

Several reports of international organizations combating crime also prove the cooperation of criminal groups from different peoples, nationalities and ethnicities. Thus, according to Europol, heroin smuggling in the European Union is not controlled or organized by merely one single criminal organization, but carried out through a cooperation and partnership network of Turkish organizations and some other criminal groups, which are mainly from the Western Balkans (Mapo, 2013).

The phenomenon of cooperation between criminal groups with different ethnic or religious affiliations in the Balkans is again evidence of the fact that organized crime knows no laws, no state borders, no nation or religion, but only their material interests ( Riedeland \& Marnix, 2009). Therefore, it can be concluded that "The Balkans is a region where people with different ethnic or religious background fight against each other and at the same time cooperate with each other in matters of crime (Kauzlarich, 2006)."

\section{Challenges in combating organized crime in the ballkans}

The fight against organized crime cannot be carried out without understanding this phenomenon at a core level and without political will and institutional determination. Current practices of this fight in several Balkan 
countries are faced with challenges and problems of different natures, such as:

\section{The Reluctance Of State Authorities}

In most Balkan countries, some offenders had had previous militant careers or had been members of the opposition movement against the communist regime. These people had been promoted in their countries as heroes fighting for freedom, for the protection of the state or for democracy. In cases where these individuals were charged with any criminal offense or were caught red-handed, they were usually punished only symbolically, even though some of them were deeply involved in criminal activities.

In other cases, government authorities have often been reluctant to deal with the fight against organized crime out of fear of different threats, lack of motivation due to social insecurity or low salaries and professional uncertainty. Some of the officials who have acted this way had been promoted through family ties or political influence and not in accordance with their real professional values. As a result, they have been vulnerable to pressure and intimidation, which has considerably increased the amount of interference in the internal affairs of the police and the justice system in some Balkan countries.

\section{Involvement Of Officials In Illegal Activities}

In some Balkan countries, state institutions have been unable to successfully combat organized crime because of their involvement in corruption and the involvement of official or political structures in criminal activities. This phenomenon has been influencing the development of organized economic crime, ware piracy and organized scientific crime in most of the Balkan states more than any other factor.

\section{Lack Of Transparency And Cooperation Between Local And International Institutions}

In some cases, the lack of cooperation between local and international institutions, in particular the phenomenon of insufficient transparency of the work of the international institutions in Kosovo and Bosnia, has also proven to be an impediment to the successful achievement of their primary mission: combating organized crime. These phenomena have contributed to creating a climate of distrust and an environment where local and international institutions in Kosovo and Bosnia blame each other for their mistakes or failures in the fight against organized crime and corruption. 


\section{Lack Of Effective Cooperation Between The Balkan States}

Despite the fact that the Balkan states have left behind the times when they had been reluctant to cooperate with each other, it is obvious that they have not yet established effective forms of cooperation with each other. On the other hand, the rapid development of organized crime beyond language, geographical and political barriers on the Balkans and especially its transnational and international nature, necessitate the need to overcome any historical relics and to develop new forms of mutual cooperation among countries in the region.

In fact, with the help of the international community, the countries in the region ratified the "Initiative for Cooperation in South East Europe" by setting up the SECI Center for establishing cooperation in the field of policing and customs and the SELEC Center for Legal Cooperation between countries of the region in 1999 (UNODC, 2010). These countries have also ratified the Convention on Police Cooperation in Southeast Europe, the UN Convention against Transnational Organized Crime, the UN Convention against Corruption and the Second Additional Protocol to the European Convention on Mutual Assistance in Criminal Matters.

Based on such international acts, regional states are obliged to cooperate closely with each other, to develop joint investigations and to set up joint investigative authorities in order to combat organized crime. However, despite these international obligations, current practices have proven that state borders, visa requirements and various customs barriers in the Balkans have not served as obstacles for cooperation between criminal groups until now, but merely as obstacles for the cooperation between the institutions of the regional countries in the fight against organized crime.

\section{Conclusion}

Organized crime is a widespread phenomenon all over the world. Wherever organized crime is present, it affects the political stability, puts the legal system at risk, threatens social security and violates human rights. As such, organized crime amounts to a threat to the society in the Balkan countries. These countries are aware of the risks organized crime represents and therefore, they have taken a range of necessary measures by building a solid legal foundation, by reorganizing and reforming state institutions and by continuously improving the cooperation between national and international institutions in order to facilitate the development of a more successful war against organized crime. Although these measures have been taken and the fight against the organized crime has been advanced to a top priority, its forms and dimensions still represent one of the main obstacles for the EU integration-process in some of these countries. 
What is most surprising is the fact that in the Balkans, neither the blood-shedding during the political conflicts of the last century nor strict visa requirements, tough border controls and high customs barriers have prevented the regional cooperation between organized criminal groups - even those belonging to "opposed" nationalities. This means that political conflicts and state borders in the Balkans have served as obstacles for establishing effective cooperation between countries of the region in the fight against organized crime and other forms of criminal activities rather than as facilitators in preventing and fighting organized crime.

Current practices in the fight against organized crime have shown that this war cannot be fought with the desired success just by approving laws according to European standards and reforming institutions of law enforcement. The introduction of new forms of organized crime necessitates the need for specialized joint institutions consisting of the police, the prosecution and the courts, based on European practices, as well as continuous education of their personnel on the issues of criminology, law, economics, banking, finance, financial auditing, etc.

The Balkan states should also abandon the old practices of state institutions acting only within their administrative limits and begin to build new forms of cooperation with other competent institutions. Regarding this aspect, the establishment of joint authorities consisting of police officers, prosecutors and courts would give a new impetus to the fight against organized crime.

As a matter of fact, the fight against organized crime in the Balkans should not be seen or understood only as a duty or responsibility of one state. The success of the fight against organized crime in the Balkans depends to a certain extent also on the cooperation and networking between the various national and international stakeholders. Therefore, the establishment of cooperation between countries of the region is an imperative which must be developed in compliance with the obligations arising from the SELEC Convention (Southeastern Law Enforcement Center) and the Police Cooperation Convention for Southeast Europe (Vienna Convention). Also, countries of the region should strengthen their cooperation with relevant organizations and other international institutions, such as INTERPOL, EUROPOL, UNODC (United Nations Office on Drugs and Crime), INCB (International Board of Narcotics Control) and EMCDDA (European Monitoring Centre for Drugs and drug Addiction). At the end, it can be stressed that the real possibilities of the Balkan states, as regards the common assessment of the situation, the identification of the aforementioned problems and coordinated action, might hopefully be able to turn the Balkans into a region where the different peoples may live together 
in mutual peace and harmony and enjoy continual perspectives and where human rights are not endangered by organized crime.

\section{References:}

\section{Books}

Briesen, Detlef (2005): Drogenkonsum und Drogenpolitik in Deutschland und der USA. Historischer Vergleich, Campus Verlag, Frankfurt am Main.

Hobsbawm, Eric (2005): Nationen und Nationalismus. Mythos und Realität seit 1780. Campus Verlag.

Okey, Robin (2007). Taming Balkan nationalism. New York: Oxford University Press.

Schmidbauer, W. \& vom Scheid, J, (1990): Handbuch der Rauschdrogen. 4. Auflage, Nymphenburger Verlag.

Riedeland, M. \& Eichelberg, M. (2009): Regional cooperation in South Eastern Europe - The aftermath of the Stability Pact, Program for Foreign and Security Policy. Skopje.

\section{Journals}

Kauzlarich, Richard (2006): Black Sea and Caspian Sea Symposium March 9-10.

National Defense Intelligence College Washington, DC

Krasniqi, Kolë (2009): Einige Merkmale des organisierten Verbrechens in Kosovo und in den übrigen Balkanstaaten.

Heidelberg, Forensik 10/2009.

Stojarova, Vera (2012): Organized Crime in the Western Balkans.

HUMSEC Journal Issue 29. Juni 2012.

Skopje (2008): Local Strategy and Action Plan for the City of Skopje drugs in $2008-2013$.

Preseva Jone (2013): Cigarettes with "Republic of Kosovo" occupy kiosks in "Srpska Republika" and Serbia.

Riegler, Henriette (2003): Contextualizing Criminality and Security in South Eastern Europe.

Crushing Crime in South East Europe: A Struggle of Domestic, Regional and European Dimensions" (Volume II, Number 2).

\section{Website}

Amnesty International (2004): Trafficked Women and Girls Have Human Rights. . [Accessed 10th March 2016] Available from World Wide Web: http://amnesty.org/en/library/ asset/EUR70/012/2004/en/38414de4-d5df11dd-bb24-1fb85fe8fa05/eur700122004en.html

Daskalović, Zoran (2003): Corruption and Organized Crime. Croatia: Crime and Corruption Continue. [Accessed 10th March 2016] Available 
from

World

Wide

Web:

http://www.aimpress.ch/dyn/dos/archive/data/2003/30725-dose-01-02.htm.

Department of Crime Problems (2005): Organized Crime Situation Report 2005. Focus on the threat of Economic crime. Council of Europe. Strasbourg. [Accessed 10th March 2016] Available from World Wide Web:

organisedcrime/Report2005E.pdf

Der Standard (2010): Geldwäsche-Ermittlungen gegen Ex-General Zagorec: [Accessed 10th March 2016] Available from World Wide Web: http://derstandard.at/ 1267132357857/Vaduz-wird-bei-Hypo-aktivGeldwaesche-Ermittlungen-gegen-Ex-General-Zagorec

European Commission, Regional Project CARPO (2006): Crime Situation Report on Economic and Organized Crime in South-eastern Europe. [Accessed 10th March 2016] Available from World Wide Web: http://.coe.int/t/dghl/cooperation/economiccrime/organisedcrime/projects/car po/Pctc_2006_20alb.pdf

European Parliament's Committee on Civil Liberties, Justice and Home Affairs (2012): Europe's Crime-Terror Nexus: Links Between Terrorist Groups and organized crime in the European Union, Policy Department C: Citizens' Rights and Constitutional Affairs, European Parliament, Brussels. . [Accessed 10 ${ }^{\text {th }}$ March 2016] Available from World Wide Web: http:///europarl.europa.eu/document/activities/cont/201211/20121127ATT56 707/20121127ATT56707EN.pdf

European School Survey Project on Alcohol and Other Drugs (2011): UNODC Programme for South Eastern Europe and Paris Pact Initiative, Drug Situation Analysis Report, Paris. [Accessed 10th March 2016] Available from World Wide Web: http://msb.gov.ba/dokumenti/DSAR. SEE.published.pdf

Europol Annual Report 2011: Allgemeiner Bericht über die Tätigkeiten von Europol. Luxemburg. [Accessed 10th March 2016] Available from World Wide

Web: https://www.europol.europa.eu/sites/default/files/publications/qlab11001den. pdf

Europol SOCTA (2013): The EU Serious and Organized Crime Threat Assessment, the European Police Office. [Accessed 10th March 2016] Available from World Wide Web: https://www.europol.europa.eu/sites/default/files/publications/socta2013.pdf Qaja, Evis (2012): Stigma and anti - drugs policies in Albania. [Accessed 10th March 2016] Available from World Wide Web: http://drogriporter.hu/files/eudrugpolicy/ Stigmatizimi.pdf

Hislope, Robert (2002): Calm before the storm? The impact of cross-border 
networks, corruption and smuggling on Macedonia's stability and security in the region, Foundation Open Society Institute Macedonia. [Accessed 10th March 2016] Available from World Wide Web: http://www.antikorupcija.org.mk/_resursi_dokumenti_submit.asp?id=97

Republik Österreich Parlament (2006): Police Cooperation Convention for Southeast Europe. [Accessed 10th March 2016] Available from World Wide Web: http://www.parlament.gv.at/ PAKT/VHG/XXIV/I/I_00915/imfname_196591.pdf

Region Press (2013): Arms smugglers (Albanian - Serbian), from 30 days in custody. [Accessed 10th March 2016] Available from World Wide Web: http://rajonipress.com/shfleto-artikujt.php?id=9199

Sebouh Baghdoyan (2003): Drug Trafficking in South East Europe, United Nations Office on Drug and Crime (UNODC). [Accessed 10th March 2016] Available from World Wide Web http://.bmlv.gv.at/pdf_pool/publikationen/crime_baghd.pdf Spiegel Online (2010): Topographie der Mafia. Handelsrouten für Amphetamine und Ecstasy. [Accessed 10th March 2016] Available from World Wide Web http://www.spiegel.de/fotostrecke/topografie-der-mafiadon-vito-wohnt-gleich-um-die-ecke-fotostrecke-59824-8.html

UN Convention against Corruption (UNCAC); http://www.un.org/depts/german/uebereinkommen/ar58004-oebgbl.pdf UN Convention against Corruption (UNCAC) (2006): Übereinkommen der Vereinten Nationen gegen Korruption.[Accessed 10th March 2016] Available from World Wide Web: http://www.un.org/depts/german/uebereinkommen/ar58004-oebgbl.pdf UN Convention against Transnational Organized Crime (UNTOC) (2004): United Nations Convention against transnational organized crime and the protocols thereto. [Accessed 10th March 2016] Available from World Wide Web: uebereinkommen/ar55025anlage1-oebgbl.pdf

United Nations Office on Drugs and Crime (UNODC) (2015): Regional Framework Programme for South Eastern Europe. [Accessed 10th March 2016] Available from World Wide Web: http://unodc.org/documents/southeasterneurope//UNODC_Regional_Progra mme_South_Eastern_Europe_December2012.pdf

United Nations Office on Drugs and Crime (UNODC) (2011): The Global Afghan Opium Trade, A Threat Assessment. [Accessed 10th March 2016] Available from World Wide Web: http://www.unodc.org/documents/dataand analysis / Studies / Global_Afghan_Opium_Trade_2011 web.pdf United Nations Office on Drugs and Crime (UNODC) (2010): Transnational Organized Crime Threat Assessment (TOCTA). [Accessed 10th March 
2016] Available from World Wide Web: http://www.unodc.org/documents/data-andanalysis/tocta/TOCTA_Report_2010_low_res.pdf United Nations Office on Drugs and Crime (UNODC) (2009): Heroin. [Accessed 10th March 2016] Available from World Wide Web: https://www.unodc.org/documents/data-and-analysis/tocta/5.Heroin.pdf United Nations Office on Drugs and Crime (UNODC) (2011): World Drug Report. [Accessed 10th March 2016] Available from World Wide Web: http://www.unodc.org/documents/data-andanalysis/WDR2011/World_Drug_Report_2011_ebook.pdf United Nations Office on Drugs and Crime (UNODC) (2012): World Drug Report 2012. [Accessed 10th March 2016] Available from World Wide Web: http://www.unodc.org/documents/data-andanalysis/WDR2012/WDR_2012_web_small.pdf United Nations Office on Drugs and Crime (UNODC) (2010): Human Trafficking: Handbook for international cooperation. [Accessed 10th March 2016] Available from World Wide Web: http://www.unodc.org/documents/southeasterneurope/GuidelinesAlbanian.pdf 